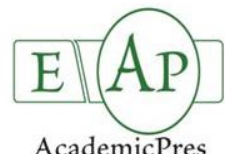

\title{
Revegetation of Abandoned Sulphur Flotation Waste in Keçiborlu, Isparta/Turkey: Heavy Metals Concentrations of Growing Media and Agropyron elongatum Grass
}

\author{
Huseyin KALKAN, Mustafa KAPLAN, Șule ORMAN* \\ Akdeniz University, Faculty of Agriculture, Department of Soil Science and Plant Nutrition, Antalya, Turkey; hkalkan@akdeniz.edu.tr, \\ mkaplan@akdeniz.edu.tr, suleorman@akdeniz.edu.tr (*orrespondingauthor)
}

\begin{abstract}
The main objectives of the study are to evaluate the effectiveness of using amendment materials (calcareous soil and farmyard manure) and to grow Agropyron elongatum (tall wheat grass) for the revegetation of sulphur flotation waste in tailing ponds. Calcareous soil (CS) at 10,20,30,40\% and farmyard manure (FYM) at 4, $8 \%$ were applied to the flotation waste (FW). $\mathrm{pH}$, electrical conductivity (EC), DTPA-extractable $\mathrm{Fe}, \mathrm{Zn}, \mathrm{Mn}, \mathrm{Cu}, \mathrm{Ni}, \mathrm{Cr}, \mathrm{Pd}, \mathrm{Cd}$, Co concentrations of growing media, also, total $\mathrm{Fe}, \mathrm{Zn}, \mathrm{Mn}, \mathrm{Cu}, \mathrm{Ni}, \mathrm{Cr}, \mathrm{Pd}, \mathrm{Cd}$, Co concentrations of plants were analysed together with the dry weight yield of the plant which were determined at end of the experiment. The results have shown that $\mathrm{pH}$, shoot $\mathrm{Zn}, \mathrm{Mn}, \mathrm{Cu}$ and $\mathrm{Pb}$ concentrations increased by CS-alone but this increment tended to decrease by FYM. The EC, DTPA-extractable Fe, Zn, Mn, $\mathrm{Ni}, \mathrm{Cr}, \mathrm{Co}$ and shoot $\mathrm{Fe}, \mathrm{Ni}, \mathrm{Cr}$, Co concentrations were decreased by CS-alone, but this decline tended to increase by FYM. There was no change in DTPA-extractable Pb and Cd concentrations between CS and CS with FYM. The dry weight of the plant shoots increased CS with FYM more than CS-alone. The plant grew well and had high cover in CS with FYM treatments compared to CS-alone. However this work indicates that $A$. elongatum can be used to revegetate sulphur flotation waste, further studies with different plant species are needed in order to obtain better plant cover in revegetation efforts.
\end{abstract}

Keywords: calcareous soil, farmyard manure, grass, inorganic waste, phytoremediation, reclamation, tailings

\section{Introduction}

Abandoned tailings which are the minerals processing residues around former mine plants constitute a major source of environmental contamination throughout the world. Tailings are often almost completely devoid of vegetation due to toxic levels of heavy metals and unfavourable edaphic conditions. The bare surfaces of tailings are susceptible to wind and water erosion and act as continuous source of metal contaminators to the surroundings (Shu et al., 2005). The release of metals from mine sites takes place mainly through acid mine drainage and erosion of waste dumps and tailings deposits (Salomons, 1995). These pollutant effects can reach local and, in some cases, regional scales (Rybicka, 1996). In a study, investigating environmental effects of sulphur flotation waste ponds in Keçiborlu, Isparta/Turkey, an increasing concentration gradient for total and DTPAextractable heavy metal in surface soil of both agricultural lands and centre of Keçiborlu district was detected toward the waste ponds (Yazar, 2010). Heavy metals in the soil of old mining areas, besides affecting the productivity of their ecosystems, could also affect animal and human health (Gutierrez-Gines et al., 2010).
Many abandoned mines and their tailing ponds are barren or have minimal vegetation to slow natural colonization. Common physical and chemical limitations to plant growth on mine tailings include: low $\mathrm{pH}$, high salt content, lack of organic matter and plant nutrients, metal toxicities, high bulk density, lack of soil structure, slow water infiltration, low water retention, and low air permeability (Henriquez and Fernandez, 1991; Wong et al., 1998; Wong, 2003). Inorganic and organic amendments are useful for stabilization of mine soil prior to revegetation (Alvarenga et al., 2008). Revegetation can be used for in situ reclamation of mine wastes, and this technique is also considered as the most suitable to achieve long term reclamation (Tordoff et al., 2000). Vegetation can provide effective protection against wind carried polluted particles, reducing runoff and the overland flow of water and sediments. Vegetation may also improve nutrient conditions in the soil and form the basis for the establishment of a self-sustaining vegetative cover (Norland and Veith, 1995). Revegetation would require the addition of lime and/or organic matter to facilitate plant growth and increase the diversity of plant species (Conesa et al., 2007). 
341

Organic residues (e.g. manure, compost, sewage sludge) are increasingly being considered in land rehabilitation (Walker et al., 2004; Brown et al., 2005; Pérez-de-Mora et al., 2006). The addition of organic matter to mine soils can significantly improve the physical nature of the root medium, especially by improving water and nutrient holding capacity, supply of plant nutrients in a slow release form, facilitating plant establishment and in situ chemical immobilization of metals, reducing leachability and phytotoxicity (Tordoff et al., 2000).

Therefore, soil acidity is the limiting factor for the establishment of vegetation in mine wastes, it is common practice to apply liming materials to overcome some of the problems associated with soil acidity (Wong, 2003; Sutton and Dick, 1987; Ye et al., 1999). Alkaline amendments reduce the concentration of metals in soil solution by raising soil $\mathrm{pH}$, thereby allowing the formation of insoluble metal precipitates, complexes and secondary minerals (Basta et al., 2001). Soils polluted with sulphur-mine wastes should be remediated by using inorganic materials containing $\mathrm{CaCO}_{3}$ (higher than $40 \mathrm{~g}$ $\mathrm{CaCO}_{3} / \mathrm{kg}$ dry soil) (Del Moral et al., 2010). The applications of calcareous soil and farmyard manure increased the soil's $\mathrm{pH}$, decreased electrical conductivity (EC) and DTPA-extractable concentrations of $\mathrm{Fe}, \mathrm{Zn}, \mathrm{Mn}, \mathrm{Cu}, \mathrm{Ni}, \mathrm{Cr}, \mathrm{Pb}$ and $\mathrm{Cd}$ in sulphur mine tailings, and also increased shoot dry weight of Zea mays L. plant (Orman and Kaplan, 2007).

Choosing the plant material is very important for revegetation of mine wastelands. Plants should have to develop an extensive root system and a large amount of biomass in the presence of high concentrations of heavy metals, in order to keep translocation of metals from roots to shoots as low as possible (Wong, 2003; Rizzi et al., 2004; Mendez and Maier, 2008). Some Agropyron species, such as $A$. desertorum and $A$. intermedium have been used for mine reclamation (Williamson et al., 1982). A. elongatum has also been used to grow on salt-affected lands (Roundy, 1985).

The main objective of the present study was to evaluate the effects of a farmyard manure and calcareous soil in the remediation of a sulphur flotation waste as, also, called sulphur mine tailings and to determine the possibility of using $A$. elongatum (tall wheat grass) in its revegetation.

\section{Materials and methods}

\section{Experimental materials}

The abandoned sulphur flotation waste ponds of Keçiborlu Sulphur Factory were located in Keçiborlu/Isparta/Turkey $\left(37^{\circ} 57^{\prime} \mathrm{N}, 30^{\circ} 18^{\prime} \mathrm{E}\right)$ with a mean annual rainfall $615 \mathrm{~mm}$, which falls in winter and spring months. The wastes from the flotation of sulphur ores were stored permanently in the tailing ponds, approximately up to 1 million tons (Fig. 1). The sulphur flotation waste ponds requires revegetation to reduce the environmental impact, which is a major source of heavy metal pollution in the local environment, owing to dust below and from leaching of the products of mineral weathering into nearby watercourses. The sulphur flotation waste was collected from the tailing ponds form $0-20 \mathrm{~cm}$ depths. The extremely calcareous soil was taken from the campus area of Akdeniz University in Antalya, Turkey. The soils were classified as Lithic Xerorthent. The farmyard manure was supplied by a local farm. All samples (flotation waste, soil and farmyard manure) were air dried and screened through a $4 \mathrm{~mm}$ mesh sieve before use. $A$. elongatum (tall wheat grass) was grown as experimental plant.

\section{Experimental design}

The greenhouse pot trial was designed to test the growth of A. elongatum in sulphur flotation waste amended with calcareous soil and farmyard manure. A total of $6 \mathrm{~kg}$ of experimental materials (Flotation Waste $(\mathrm{FW})+$ Calcareous Soil $(\mathrm{CS})+$ Farmyard Manure (FYM) $=$ Growing Media $)$ at predetermined ratios (Tab. 1) were thoroughly mixed and then $\mathrm{N}: \mathrm{P}: \mathrm{K}$ fertilizer $(15: 15: 15)$ was added at a rate equivalent to $150 \mathrm{~kg} \mathrm{da}^{-1}$ per pot. The pots $(510 \times 165 \times 125 \mathrm{~mm})$ were filled up with growing mediums. There were prepared four replicates for each treatment.

Each pot was hand broadcasted with seeds $A$. elongatum, at rate of $100 \mathrm{~g} \mathrm{~m}^{-2}$. The pots were arranged in a randomized factorial design and were equally watered in greenhouse and allowed to grow for 3 months (from the beginning of June until the end of September). The above-ground parts (shoots) of the plants were harvested 5 times during the experiment. After harvest, plant samples were washed with tap water, rinsed three times with deionized water and then oven-dried at $65^{\circ} \mathrm{C}$ to a constant weight. Dry weight yields were recorded. The dried plants resulted from the 5 harvests were homogeneously combined together to obtain a composite plant sample for each treatment. After this process, plant samples were reduced to powder by an electric mill and analysed to determine the concentrations of $\mathrm{Fe}, \mathrm{Zn}, \mathrm{Mn}, \mathrm{Cu}, \mathrm{Ni}, \mathrm{Cr}, \mathrm{Pb}, \mathrm{Cd}$, Co. The growing media samples were taken from each pot at the end of the experiment, air-dried, grounded to pass through a $2 \mathrm{~mm}$ sieve, and determined the $\mathrm{pH}, \mathrm{EC}$ (Electrical Conductivity) values and concentrations of DTPA-extractable Fe, $\mathrm{Zn}, \mathrm{Mn}$, $\mathrm{Cu}, \mathrm{Ni}, \mathrm{Cr}, \mathrm{Pb}, \mathrm{Cd}$ and $\mathrm{Co}$.

Tab. 1. Experimental design for pot trial

\begin{tabular}{lc}
\hline Treatments & A total of 6 kg per pot (w/w) \\
\hline FWCS & $90 \% \mathrm{FW}+10 \% \mathrm{CS}$ \\
\hline FWCS $_{20}$ & $80 \% \mathrm{FW}+20 \% \mathrm{CS}$ \\
FWCS $_{30}$ & $70 \% \mathrm{FW}+30 \% \mathrm{CS}$ \\
\hline FWCS $_{40}$ & $60 \% \mathrm{FW}+40 \% \mathrm{CS}$ \\
FWCS $_{10} \mathrm{FYM}_{4}$ & $86 \% \mathrm{FW}+10 \% \mathrm{CS}+4 \% \mathrm{FYM}$ \\
FWCS $_{10} \mathrm{FYM}_{8}$ & $82 \% \mathrm{FW}+10 \% \mathrm{CS}+8 \% \mathrm{FYM}$ \\
\hline FWCS $_{20} \mathrm{FYM}_{4}$ & $76 \% \mathrm{FW}+20 \% \mathrm{CS}+4 \% \mathrm{FYM}$ \\
FWCS $_{20} \mathrm{FYM}_{8}$ & $72 \% \mathrm{FW}+20 \% \mathrm{CS}+8 \% \mathrm{FYM}$ \\
FWCS $_{30} \mathrm{FYM}_{4}$ & $66 \% \mathrm{FW}+30 \% \mathrm{CS}+4 \% \mathrm{FYM}$ \\
FWCS $_{30} \mathrm{FYM}_{8}$ & $62 \% \mathrm{FW}+30 \% \mathrm{CS}+8 \% \mathrm{FYM}$ \\
\hline
\end{tabular}

Also, air-dried flotation waste, calcareous soil and farmyard manure were grounded to pass through a $2 \mathrm{~mm}$ sieve and some physico-chemical parameters were analysed prior to the plant growth experiment (Tab. 2).

\section{Analytical chemistry}

The $\mathrm{pH}$ and $\mathrm{EC}$ values were measured in $\mathrm{H}_{2} \mathrm{O}$ (1-2.5 soil: deionized water). The $\mathrm{CaCO}_{3}$ content was determined by using a Scheibler calcimeter. The total $\mathrm{N}$ was done by using modified Kjeldahl procedure (Kacar, 1994). The available P was extracted by sodium bicarbonate (Olsen and Sommers, 1982), exchangeable $\mathrm{K}^{+}, \mathrm{Ca}^{+2}, \mathrm{Mg}^{+2}, \mathrm{Na}^{+}$were extracted by ammonium acetate (Kacar, 1994), extractable Fe, Zn, Mn, Cu, Ni, Cr, Pb, $\mathrm{Cd}$ and $\mathrm{Co}$ were extracted by diethylenetriaminepentaacetic 

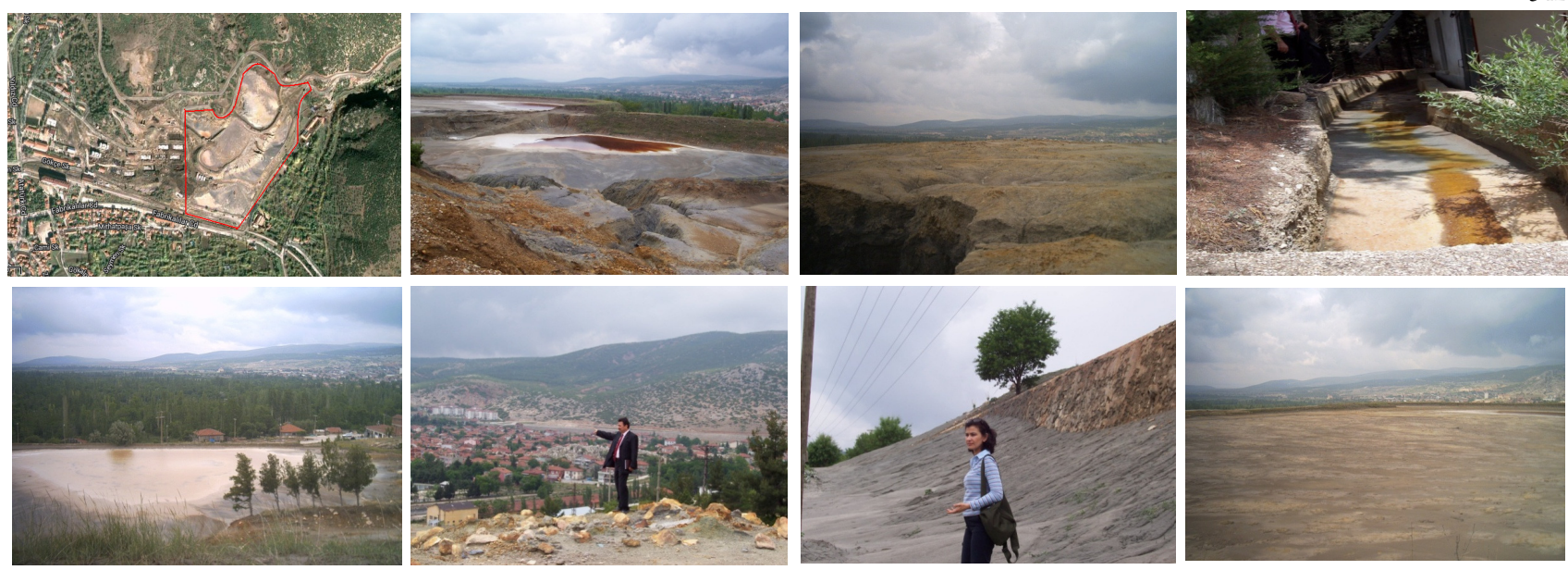

Fig. 1. General views of the sulphur flotation waste (sulphur mine tailings) in Keçiborlu, Isparta, Turkey

acid-DTPA (Lindsay and Norvel, 1978) and then concentrations were determined by Induced-Coupled Plasma with Optical Emission Spectrophotometer (ICP-OES).

Plant samples (shoots) were digested with $\mathrm{HNO}_{3}$ and $\mathrm{HClO}_{4}(4: 1)$ (Kacar and Inal, 2008). The concentrations of Fe, $\mathrm{Zn}, \mathrm{Mn}, \mathrm{Cu}, \mathrm{Ni}, \mathrm{Cr}, \mathrm{Pb}, \mathrm{Cd}$ and $\mathrm{Co}$ in the digests were determined by ICP-OES.

The data were analysed by standard ANOVA procedures and their significances were based on the $\mathrm{p}<0.05$ level using the Duncan's Multiple Range Test.

Tab. 2. General properties of sulphur flotation waste, calcareous soil and farmyard manure

\begin{tabular}{|lccc}
\hline Parameters & $\begin{array}{c}\text { Flotation } \\
\text { Waste }\end{array}$ & $\begin{array}{c}\text { Farmyard } \\
\text { Manure }\end{array}$ & Calcareous Soil \\
\hline $\mathrm{pH}$ & 3.12 & 7.62 & 7.97 \\
$\mathrm{EC} \mathrm{dS} \mathrm{m}$ & -1 & 4.73 & 0.16 \\
\hline $\mathrm{CaCO} \%$ & 9.99 & 9.66 & 48.25 \\
$\mathrm{~N} \%$ & 1.61 & 2.13 & 0.035 \\
\hline $\mathrm{P} \mathrm{mg} \mathrm{kg}{ }^{-1}$ & 0.038 & 3876.16 & 0.49 \\
\hline $\mathrm{K} \mathrm{mg} \mathrm{kg}^{-1}$ & 0.17 & 6767.84 & 23.87 \\
\hline $\mathrm{Ca} \mathrm{mg} \mathrm{kg}$ & 0.01 & 36362.10 & 1442.00 \\
$\mathrm{Mg} \mathrm{mg} \mathrm{kg}^{-1}$ & 1442.00 & 5116.83 & 130.00 \\
\hline $\mathrm{Na} \mathrm{mg} \mathrm{kg}$ & 406.00 & 0.15 & 15.01 \\
\hline $\mathrm{Fe} \mathrm{mg} \mathrm{kg}^{-1}$ & 4.92 & 3582.50 & 3.53 \\
\hline $\mathrm{Zn} \mathrm{mg} \mathrm{kg}$ & 6250.00 & 152.58 & 1.18 \\
\hline $\mathrm{Mn} \mathrm{mg} \mathrm{kg}$ & 8.17 & 75.58 & 3.00 \\
\hline $\mathrm{Cu} \mathrm{mg} \mathrm{kg}$ & 53.21 & 2.56 & 0.59 \\
\hline $\mathrm{Ni} \mathrm{mg} \mathrm{kg}$ & 10.30 & 28.09 & 0.11 \\
\hline $\mathrm{Cr} \mathrm{mg} \mathrm{kg}$ & 64.84 & 57.56 & 0.02 \\
\hline $\mathrm{Pb} \mathrm{mg} \mathrm{kg}$ & 14.86 & 5.35 & 0.16 \\
\hline $\mathrm{Cd} \mathrm{mg} \mathrm{kg}$ & 0.53 & 0.56 & 0.01 \\
\hline $\mathrm{Co} \mathrm{mg} \mathrm{kg}$ & 0.13 & 0.27 & 0.04 \\
\hline
\end{tabular}

\section{Results and discussions}

The $p H, E C$ values and DTPA-extractablemetal concentrations ingrowingmedia

The results of $\mathrm{pH}, \mathrm{EC}$ and DTPA-extractable metal concentrations of growing media were given in Tab. 3 and Fig. 2. The $\mathrm{pH}$ of growing media increased by CS-alone, but this increment tended to decrease by FYM. Also, the EC was decreased by CS-alone, but this decline tended to increase by FYM. When contaminated soil is moist and exposed to air, oxidation and hydrolysis of sulphides $\left(\mathrm{S}^{2}\right)$ in the waste leads to the formation of sulphuric acid, thus lowering $\mathrm{pH}$ and greatly increasing heavy metal solubility (Williamson and Johnson, 1981; Simón et al., 1999; Clemente et al., 2003). The application of both lime and organic matter to contaminated soil by mineral sulphides caused increasing $\mathrm{pH}$ and decreasing EC in soil (Clemente et al., 2003).

The concentrations of DTPA-extractable Fe, $\mathrm{Zn}, \mathrm{Mn}, \mathrm{Ni}$, $\mathrm{Cr}$ and Co concentrations were decreased by CS-alone, but this decline tended to increase by FYM. There was no change in $\mathrm{Pb}$ and $\mathrm{Cd}$ concentrations between CS and CS with FYM. The application of calcareous soil led to increased $\mathrm{pH}$ while consequently extractable metal concentrations were decreased in growing media. The $\mathrm{pH}$ effect was greater than that of metal complex formation by soluble organic matter (Walker $e t$ al., 2004). Application of fresh manure can increase heavy metal solubility, due to the provision of soluble organic compounds which form complexes with the metals (Almås et al., 1999; Shuman, 1999). However, the humic materials, which constitute a major part of the organic matter of compost, can reduce metal solubility by formation of stable metal chelates (Ross, 1994). Differences with respect to effects on metal availability between amendment materials can be related to differences not only in the organic matter, but also in the mineral fractions ( $\mathrm{pH}$, salt content) and cation exchange capacity, as well as changes in the redox conditions of the soil (Shuman, 1999; Ross, 1994; Walker et al., 2003).

\section{Metal concentrations and dry weight yield of Agropyron elongatum shoot}

The concentrations of metal in plant shoots were given in Tab. 4 and Fig. 3. The shoot Fe, Ni, $\mathrm{Cr}$ and $\mathrm{Co}$ concentrations were decreased by CS-alone, but this decline tended to increase by FYM. The shoot $\mathrm{Zn}, \mathrm{Mn}, \mathrm{Cu}$ and $\mathrm{Pb}$ concentrations increased by CS-alone, but this increment tended to decrease by FYM. The dry weight yield of plant increased CS with FYM more than CS-alone (Fig. 3). The plant grew well and had higher cover in CS with FYM treatments compared to CSalone (Fig. 4). Farmyard manure is commonly used as tailings amendment because the addition of organic matter can significantly improve the physical characteristics and the nutrient status of mine wastes (Bradshaw and Chadwick, 
343

Tab. 3. The pH, EC values and DTPA-extractable metal concentrations in flotation waste amended with calcareous soil (CS) and farmyard manure (FYM) (as called growing media) $)^{a}$

\begin{tabular}{|c|c|c|c|c|c|c|c|c|c|c|c|}
\hline \multirow{2}{*}{ Parameters } & \multirow{2}{*}{$\mathrm{FWCS}_{10}$} & \multirow{2}{*}{$\mathrm{FWCS}_{20}$} & \multirow{2}{*}{$\mathrm{FWCS}_{30}$} & \multirow{2}{*}{$\mathrm{FWCS}_{40}$} & \multicolumn{2}{|c|}{$\mathrm{FWCS}_{10}$} & \multicolumn{2}{|c|}{$\mathrm{FWCS}_{20}$} & \multicolumn{2}{|c|}{$\mathrm{FWCS}_{30}$} & \multirow{2}{*}{$\begin{array}{c}\text { Significance } \\
\text { levels }^{\mathrm{b}}\end{array}$} \\
\hline & & & & & $\mathrm{FYM}_{4}$ & $\mathrm{FYM}_{8}$ & $\mathrm{FYM}_{4}$ & $\mathrm{FYM}_{8}$ & $\mathrm{FYM}_{4}$ & $\mathrm{FYM}_{8}$ & \\
\hline $\mathrm{pH}$ & $3.53 \mathrm{hl}$ & $5.23 \mathrm{e}$ & $6.52 \mathrm{~b}$ & $6.58 \mathrm{a}$ & 3.501 & $3.57 \mathrm{~h}$ & $4.22 \mathrm{~g}$ & $4.40 \mathrm{f}$ & $5.43 \mathrm{~d}$ & $6.30 c$ & $* * *$ \\
\hline $\mathrm{EC}\left(\mathrm{d} S \mathrm{~m}^{-1}\right)$ & $2.83 \mathrm{~b}$ & $2.57 \mathrm{~d}$ & $2.39 \mathrm{f}$ & $2.46 \mathrm{e}$ & $2.70 c$ & $2.56 \mathrm{~d}$ & $2.20 \mathrm{~g}$ & $3.14 \mathrm{a}$ & $2.70 c$ & $3.13 \mathrm{a}$ & $* * *$ \\
\hline $\mathrm{Fe}\left(\mathrm{mgkg}^{-1}\right)$ & $282.73 \mathrm{~d}$ & $221.10 \mathrm{f}$ & 100.821 & $113.70 \mathrm{~h}$ & $330.55 b$ & 324.48 c & $330.07 \mathrm{~b}$ & $354.35 a$ & $235.95 \mathrm{e}$ & $194.18 \mathrm{~g}$ & $* * *$ \\
\hline $\mathrm{Zn}\left(\mathrm{mgkg}^{-1}\right)$ & $1.16 \mathrm{de}$ & $0.58 \mathrm{~g}$ & $0.70 \mathrm{fg}$ & $0.89 \mathrm{ef}$ & $1.58 \mathrm{bc}$ & $3.46 a$ & $1.01 \mathrm{e}$ & $1.78 \mathrm{~b}$ & $1.36 \mathrm{~cd}$ & $3.36 a$ & *** \\
\hline $\operatorname{Mn}\left(\mathrm{mgkg}^{-1}\right)$ & $27.13 \mathrm{~d}$ & $22.62 \mathrm{ef}$ & $13.65 \mathrm{~g}$ & $16.00 \mathrm{~g}$ & $25.42 \mathrm{de}$ & $37.92 \mathrm{~b}$ & $34.63 \mathrm{bc}$ & $46.59 \mathrm{a}$ & $20.36 f$ & $31.21 \mathrm{c}$ & $* * *$ \\
\hline $\mathrm{Cu}\left(\mathrm{mgkg}^{-1}\right)$ & $0.96 \mathrm{~g}$ & $1.72 \mathrm{~d}$ & $2.22 \mathrm{c}$ & $2.46 \mathrm{~b}$ & $1.12 \mathrm{f}$ & $0.95 \mathrm{~g}$ & $1.52 \mathrm{e}$ & $1.67 \mathrm{~d}$ & $2.49 \mathrm{~b}$ & $2.91 \mathrm{a}$ & $* * *$ \\
\hline $\mathrm{Ni}\left(\mathrm{mg} \mathrm{kg}^{-1}\right)$ & $6.84 \mathrm{~d}$ & $5.47 \mathrm{e}$ & $3.93 \mathrm{~g}$ & $4.70 \mathrm{f}$ & $9.45 \mathrm{~b}$ & $11.22 \mathrm{a}$ & $9.00 \mathrm{~b}$ & $7.76 c$ & $4.90 \mathrm{ef}$ & $8.10 \mathrm{c}$ & $* * *$ \\
\hline $\mathrm{Cr}\left(\mathrm{mg} \mathrm{kg}^{-1}\right)$ & $0.03 c$ & $0.02 c$ & $0.02 \mathrm{c}$ & $0.02 c$ & $0.12 \mathrm{a}$ & $0.10 \mathrm{~b}$ & $0.02 c$ & $0.02 c$ & $0.02 c$ & $0.02 c$ & $* * *$ \\
\hline $\mathrm{Pb}\left(\mathrm{mgkg}^{-1}\right)$ & $0.04 \mathrm{ef}$ & $0.08 \mathrm{~d}$ & $0.13 \mathrm{~b}$ & $0.15 \mathrm{a}$ & $0.04 \mathrm{f}$ & $0.05 \mathrm{ef}$ & $0.06 \mathrm{e}$ & $0.09 \mathrm{~d}$ & $0.11 \mathrm{c}$ & $0.15 \mathrm{a}$ & $* * *$ \\
\hline $\mathrm{Cd}\left(\mathrm{mg} \mathrm{kg}^{-1}\right)$ & $0.03 \mathrm{e}$ & $0.05 c$ & $0.05 c$ & $0.06 \mathrm{~b}$ & $0.03 \mathrm{~d}$ & $0.04 \mathrm{~d}$ & $0.04 \mathrm{c}$ & $0.05 c$ & $0.05 \mathrm{~b}$ & $0.08 \mathrm{a}$ & $* * *$ \\
\hline $\mathrm{Co}\left(\mathrm{mg} \mathrm{kg}^{-1}\right)$ & $0.61 \mathrm{~d}$ & $0.35 \mathrm{~g}$ & $0.33 \mathrm{gh}$ & $0.46 \mathrm{ef}$ & $1.39 \mathrm{~b}$ & $1.77 \mathrm{a}$ & $0.96 c$ & $0.49 \mathrm{e}$ & $0.25 \mathrm{~h}$ & $0.37 \mathrm{fg}$ & $* * *$ \\
\hline
\end{tabular}

${ }^{a}$ Values are means $(n=4)$. Values in a row followed by different letters indicate significant differences $(\mathrm{p}<0.05)$ between treatments according to a Duncan's multiple range test.

${ }^{\text {bS }}$ ignificance levels: ${ }^{* * *} \mathrm{p}<0.001$
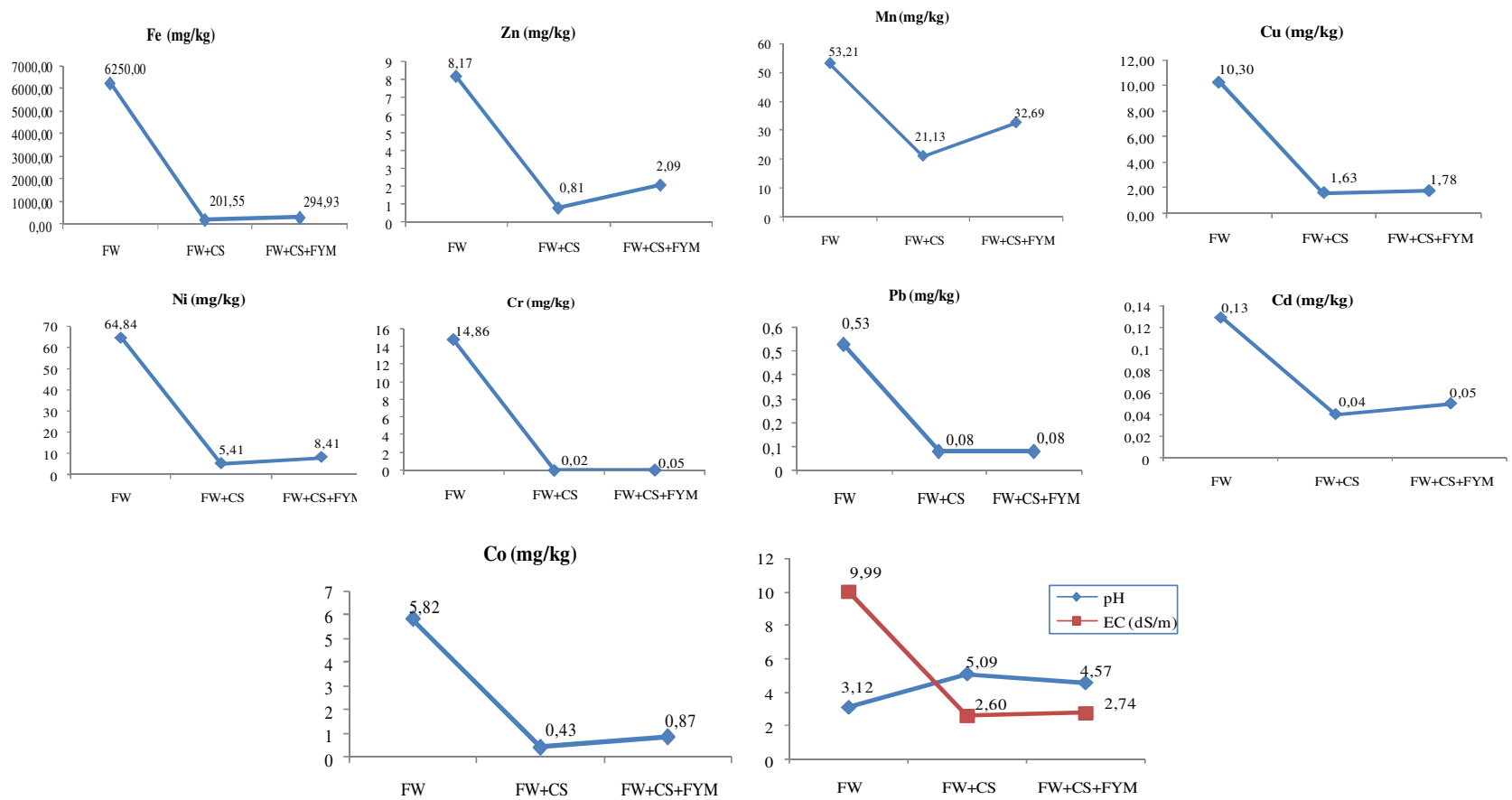

Fig. 2. The values of average $\mathrm{pH}, \mathrm{EC}$ and DTPA-extract. $\mathrm{Fe}, \mathrm{Zn}, \mathrm{Mn}, \mathrm{Cu}, \mathrm{Ni}, \mathrm{Cr}, \mathrm{Pb}, \mathrm{Cd}$, Co concentrations due to treatments of calcareous soil and calcareous soil with farmyard manure in growing media

Tab. 4. Metal concentrations of Agropyron elongatum shoot growth in flotation waste amended with calcareous soil (CS) and farmyard manure (FYM) (as called growing media) $)^{a}$

\begin{tabular}{|c|c|c|c|c|c|c|c|c|c|c|c|}
\hline \multirow{2}{*}{ Parameters } & \multirow{2}{*}{$\mathrm{FWCS}_{10}$} & \multirow{2}{*}{$\mathrm{FWCS}_{20}$} & \multirow{2}{*}{$\mathrm{FWCS}_{30}$} & \multirow{2}{*}{$\mathrm{FWCS}_{40}$} & \multicolumn{2}{|c|}{$\mathrm{FWCS}_{10}$} & \multicolumn{2}{|c|}{$\mathrm{FWCS}_{20}$} & \multicolumn{2}{|c|}{$\mathrm{FWCS}_{30}$} & \multirow{2}{*}{$\begin{array}{l}\text { Significance } \\
\text { levels }^{b}\end{array}$} \\
\hline & & & & & $\mathrm{FYM}_{4}$ & $\mathrm{FYM}_{8}$ & $\mathrm{FYM}_{4}$ & $\mathrm{FYM}_{8}$ & $\mathrm{FYM}_{4}$ & $\mathrm{FYM}_{8}$ & \\
\hline Dry weight $\left(\mathrm{gpot}^{-1}\right)$ & $25.34 \mathrm{~h}$ & $29.61 \mathrm{~g}$ & $35.33 \mathrm{e}$ & $32.57 \mathrm{f}$ & $31.85 \mathrm{f}$ & $40.25 \mathrm{~d}$ & $40.31 \mathrm{~d}$ & $46.94 b$ & $41.79 c$ & $48.54 a$ & *** \\
\hline $\mathrm{Fe}\left(\mathrm{mgkg}^{-1}\right)$ & $275.80 \mathrm{~d}$ & $256.13 \mathrm{e}$ & $239.32 \mathrm{gh}$ & $246.18 \mathrm{f}$ & $241.90 \mathrm{~g}$ & $338.20 \mathrm{a}$ & $272.70 \mathrm{~d}$ & $326.32 \mathrm{~b}$ & $296.77 \mathrm{c}$ & $237.97 \mathrm{~h}$ & *** \\
\hline $\mathrm{Zn}\left(\mathrm{mgkg}^{-1}\right)$ & $60.64 \mathrm{f}$ & $75.10 \mathrm{a}$ & $76.14 a$ & $71.23 b c$ & $66.89 \mathrm{~d}$ & $70.06 c$ & $69.27 \mathrm{~cd}$ & $73.63 \mathrm{ab}$ & $62.52 \mathrm{ef}$ & $64.07 \mathrm{e}$ & *** \\
\hline $\operatorname{Mn}\left(\mathrm{mgkg}^{-1}\right)$ & $143.89 \mathrm{c}$ & $127.18 \mathrm{~d}$ & $106.86 \mathrm{f}$ & $103.56 \mathrm{f}$ & $157.85 \mathrm{~b}$ & $196.07 \mathrm{a}$ & $117.72 \mathrm{e}$ & $82.56 \mathrm{~h}$ & $87.00 \mathrm{~g}$ & 76.521 & *** \\
\hline $\mathrm{Cu}\left(\mathrm{mgkg}^{-1}\right)$ & $1.56 \mathrm{c}$ & $1.60 \mathrm{~b}$ & $1.35 \mathrm{fg}$ & $1.64 \mathrm{~b}$ & $1.32 \mathrm{~g}$ & $1.48 \mathrm{~d}$ & $1.46 \mathrm{de}$ & $1.37 \mathrm{f}$ & $1.74 \mathrm{a}$ & $1.43 \mathrm{e}$ & *** \\
\hline $\mathrm{Ni}\left(\mathrm{mgkg}^{-1}\right)$ & $15.45 c$ & $3.22 \mathrm{~d}$ & $2.25 \mathrm{de}$ & $1.83 \mathrm{e}$ & $41.45 a$ & $27.54 \mathrm{~b}$ & $3.12 \mathrm{~d}$ & $3.26 \mathrm{~d}$ & $2.32 \mathrm{de}$ & $2.48 \mathrm{de}$ & *** \\
\hline $\mathrm{Cr}\left(\mathrm{mgkg}^{-1}\right)$ & $1.88 \mathrm{~d}$ & $1.47 \mathrm{f}$ & $1.75 \mathrm{e}$ & $1.78 \mathrm{e}$ & $1.16 \mathrm{~g}$ & $2.02 \mathrm{c}$ & $1.85 \mathrm{~d}$ & $2.55 \mathrm{a}$ & $2.59 \mathrm{a}$ & $2.29 \mathrm{~b}$ & *** \\
\hline $\mathrm{Pb}\left(\mathrm{mg} \mathrm{kg}^{-1}\right)$ & $7.82 \mathrm{~d}$ & $7.76 \mathrm{~d}$ & $14.81 \mathrm{a}$ & $10.71 \mathrm{c}$ & $8.51 \mathrm{~d}$ & $12.61 \mathrm{~b}$ & $7.99 \mathrm{~d}$ & $5.50 \mathrm{e}$ & $3.21 \mathrm{f}$ & $5.43 \mathrm{e}$ & *** \\
\hline $\mathrm{Cd}\left(\mathrm{mgkg}^{-1}\right)$ & $0.61 \mathrm{f}$ & $0.67 \mathrm{e}$ & $1.05 \mathrm{~b}$ & $0.86 \mathrm{c}$ & $0.85 c$ & $1.90 \mathrm{a}$ & $0.84 \mathrm{c}$ & $0.76 \mathrm{~d}$ & $0.37 \mathrm{~h}$ & $0.54 \mathrm{~g}$ & *** \\
\hline $\mathrm{Co}\left(\mathrm{mg} \mathrm{kg}^{-1}\right)$ & $1.16 \mathrm{c}$ & $0.32 \mathrm{de}$ & $0.35 \mathrm{~d}$ & $0.31 \mathrm{e}$ & $3.86 \mathrm{a}$ & $1.50 \mathrm{~b}$ & $<\mathrm{LD}^{\mathrm{c}}$ & $<\mathrm{LD}$ & $<\mathrm{LD}$ & $<\mathrm{LD}$ & *** \\
\hline
\end{tabular}

a Values are means $(n=4)$. Values in a row followed by different letters indicate significant differences $(\mathrm{p}<0.05)$ between treatments according to a Duncan's multiple range test.

${ }^{\mathrm{b}}$ Significance levels: ${ }^{* * *} \mathrm{p}<0.001$

${ }^{\mathrm{c}}$ Limit of detection $\left(\mathrm{LD}<0.1 \mathrm{mg} \mathrm{kg}^{-1}\right)$ 

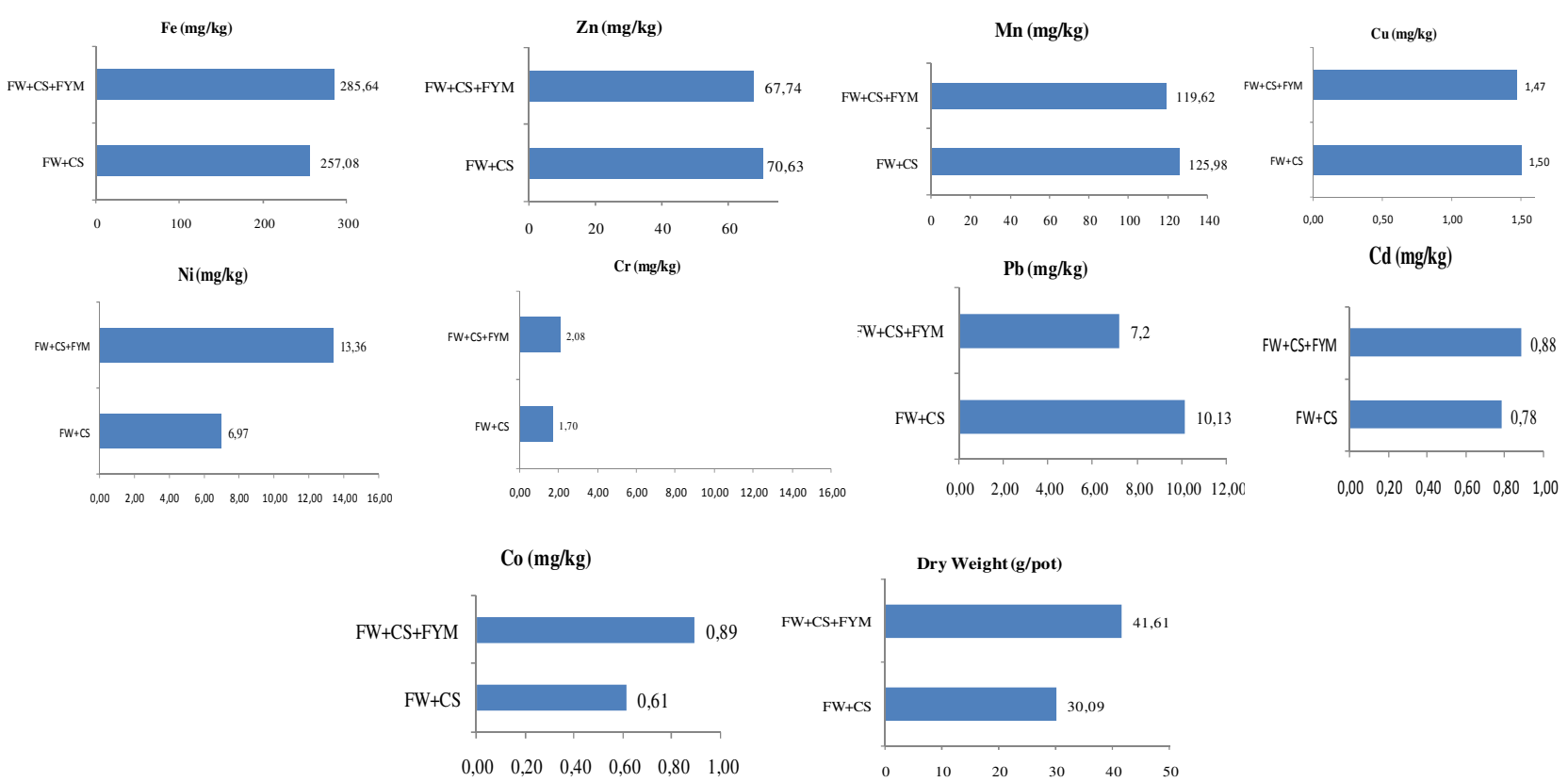

Fig. 3. The values of average $\mathrm{Fe}, \mathrm{Zn}, \mathrm{Mn}, \mathrm{Cu}, \mathrm{Ni}, \mathrm{Cr}, \mathrm{Pb}, \mathrm{Cd}$, Co concentrations and dry weight of shoot due to treatments of calcareous soil and calcareous soil with farmyard manure in growing media
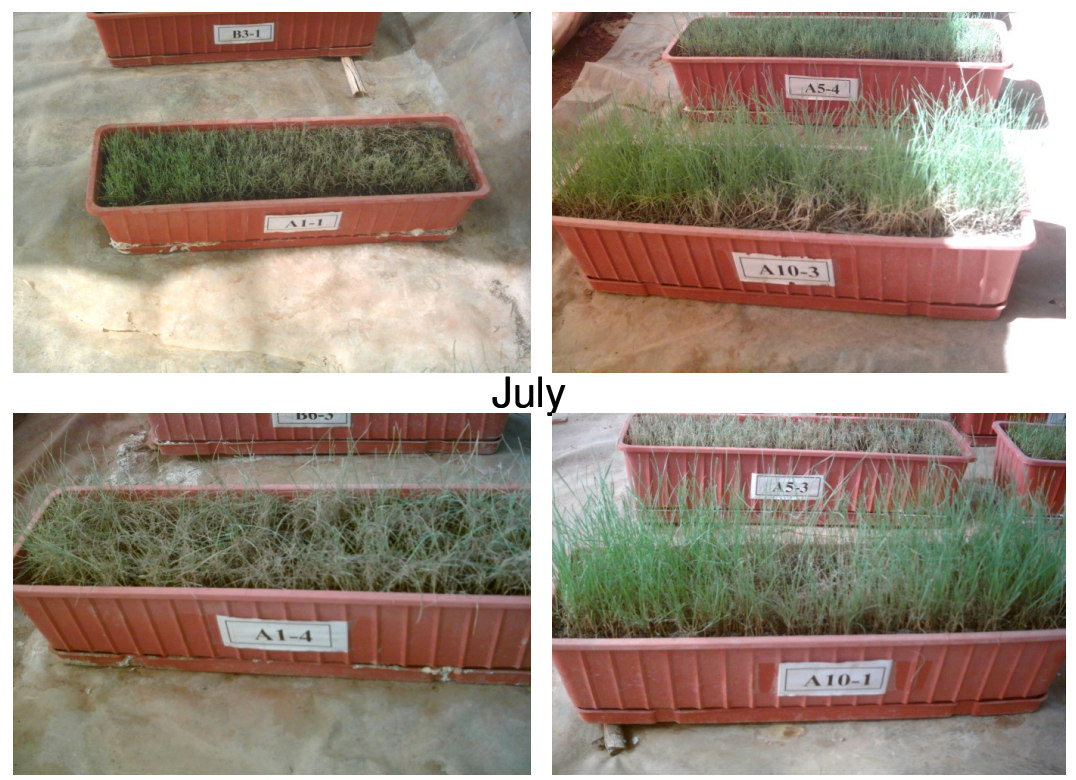

July

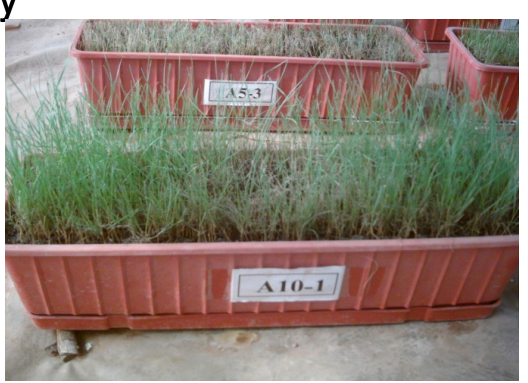

August

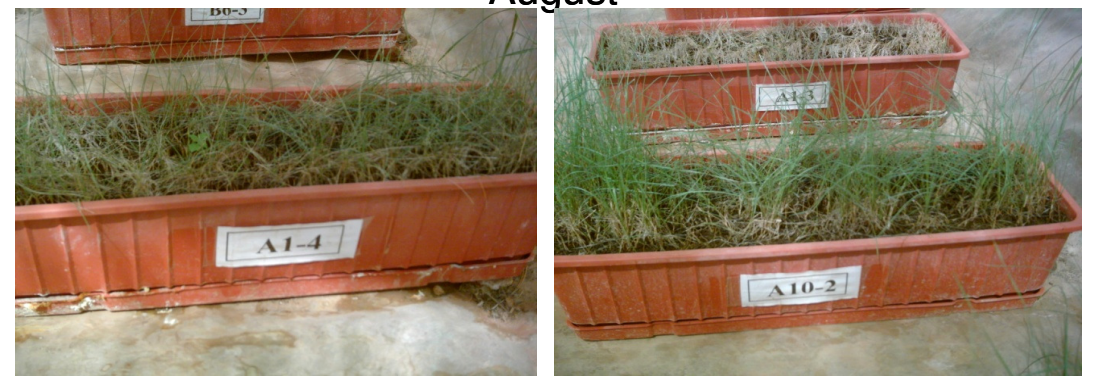

September

$90 \% \mathrm{FW}+10 \% \mathrm{CS}$

$62 \% \mathrm{FW}+30 \% \mathrm{CS}+8 \% \mathrm{FYM}$

Fig. 4. Agropyron elongatum growth during the experiment 
345

1980). In addition, both manure compost and sewage sludge contained high amounts of macronutrients $(\mathrm{N}, \mathrm{P}$, and $\mathrm{K})$ and organic carbon content, which can compensate for the nutrient deficiencies in $\mathrm{Pb} / \mathrm{Zn}$ and $\mathrm{Cu}$ tailings (Chiu et al., 2006). The effect of the organic amendments on the bioavailability of metals was difficult to observe due to the great variability of total metal concentration and $\mathrm{pH}$. In any case, $\mathrm{pH}$ seemed to be a controlling factor in metal availability, to a greater extent than the organic amendments. Liming succeeded in controlling the soil acidification in a soil affected by acid, highly toxic pyritic waste (Clemente et al., 2003).

\section{Conclusion}

DTPA-extractable heavy metal concentrations decreased with increasing $\mathrm{pH}$ in growing media caused by the applications of CS-alone to flotation waste. However, in applications of CS with FYM, heavy metal concentrations in both growing media and shoot increased, in contrast to increasing $\mathrm{pH}$ of the growing media. The higher DTPAextractable heavy metal concentrations in CS with FYM treatments compared to CS-alone is thought to be the result of chelating effect of farmyard manure. In spite of high heavy metal concentration in growing media and shoot, dry weight yield increased in plant in CS with FYM treatments. This may be due to the improvements in some growing media properties, the presence of inorganic flotation waste, as a result of farmyard manure (organic).

\section{Acknowledgments}

The authors would like to express their appreciation to the Scientific Fund of Akdeniz University (Project no: 2008.02.0121.022).

\section{References}

Almås A, Singh BR, Salbu B (1999). Mobility of cadmium-109 and zinc-65 in soil influenced by equilibration time, temperature, and organic matter. J Environ Qual 28:17421750.

Alvarenga P, Gonçalves AP, Fernandes RM, de Varennes de A, Vallini G, Duarte E, Cunha-Queda AC (2008). Evaluation of composts and liming materials in the phytostabilization of a mine soil using perennial ryegrass. Sci Total Environ 406:4356.

Basta NT, Gradwohl R, Snethen KL, Schroder JL (2001). Chemical immobilization of lead, zinc, and cadmium in smelter-contaminated soils using biosolids and rock phosphate. J Environ Qual 30:1222-1230.

Bradshaw AD, Chadwick MJ (1980). The restoration of land. Blackwell Scientific, Oxford.

Brown SL, Sprenger M, Maxemchuk A, Compton H (2005). Ecosystem function in alluvial tailings after biosolids and lime application. J Environ Qual 34:1-6.

Chiu KK, Ye ZH, Wong MH (2006). Growth of Vetiveria zizanioides and Phragmities australis on $\mathrm{Pb} / \mathrm{Zn}$ and $\mathrm{Cu}$ mine tailings amended with manure compost and sewage sludge: A greenhouse study. Bioresource Technology 97:158-170.
Clemente R, Walker DJ, Roig A, Bernal MP (2003). Heavy metal availability in a soil affected by mineral sulphides contamination following the mine spillage at Aznalcóllar (Spain). Biodegradation 14:199-205.

Conesa HM, Faz A, Garcia G, Arnaldos R (2007). Heavy metal contamination in the semiarid area of Cartagena-La Union (SE Spain) and its implications for revegetation. Fresenius Environmental Bulletin 16:1076-1081.

Del MF, Gonzalez V, Garcia I, Sanchez JA, de Haro S, Simon M (2010). Effect of organic and inorganic residues on the solubility of trace elements and phytotoxicity of mining waste. Fresenius Environmental Bulletin 19:2071-2076.

Gutierrez-Gines MJ, Pastor J, Hernandez AJ (2010). Effect of Heavy metals from mine soils on Avena sativa L. and education Strategies. Fresenius Environmental Bulletin 19:2083-2086.

Henriquez FS, Fernandez JC (1991). Metal uptake and distrubition in rush (Juncus conglomerates L.) plants growing in phrites mine tailings at Lousal, Portugal. Sci Total Environ 102:253-260.

Kacar B (1994). Toprak Analizleri. Bitki ve Toprağın Kimyasal Analizleri. III. Toprak Analizleri. Ankara Üniv. Ziraat Fak. Eğitim Araştırma ve Geliştirme Vakfi Yayınları. No: 3, ss 705, Ankara (in Turkish).

Kacar B, Inal A (2008). Bitki Analizleri. Nobel Yayın No:1241, Fen Bilimleri: 63, 879 pp, Ankara (in Turkish).

Lindsay WL, Norvel WA (1978). Development of a DTPA soil test for zinc, iron, manganese and copper. Soil Sci Amer Jour 42(3):421-428.

Mendez MO, Maier RM (2008) Phytostabilization of mine tailings in arid and semiarid environments-an emerging remediation technology. Environ Health Perspect 116:278-283.

Norland MR, Veith DL (1995). Revegetation of coarse taconite iron ore tailing using municipal waste compost. J Hazard Mater 41:123-134.

Olsen SR, Sommers EL (1982). Phosphorus Soluble in Sodium Bicarbonate, p. 404-430. In: Page AL, Miller RH, Keeney DR (Eds.). Methods of Soil Analysis. Part 2. Chemical and Microbiological Properties. Agronomy Monograph 9, ASA and SSSA, Madison, WI.

Orman Ş, Kaplan M (2007). Effects of calcareous soil and farmyard manure on revegetation of sulphur mine tailings. Fresenius Environmental Bulletin 16:1295-1299.

Pérez-de-Mora A, Burgos P, Madejón E, Cabrera F, Jaeckel P, Schlote M (2006). Microbial community structure and function in a soil contaminated by heavy metals: effects of plant growth and different amendments. Soil Biol Biochem 38:327-341.

Rizzi L, Petruzelli G, Poggio G, Vigna GG (2004). Soil physical changes and plant availability of $\mathrm{Zn}$ and $\mathrm{Pb}$ in a treatability test of phytostabilization. Chemosphere 57:1039-1046.

Ross SM (1994). Retention, transformation and mobility of toxic metals in soils, p. 63-152. In: Ross SM (Ed.). Toxic Metals in Soil-Plant Systems. John Wiley and Sons Ltd., Chichester, UK. 
346

Roundy BA (1985). Root penetration and shoot elongation of tall wheat grass and basin in relation to salinity. Can J Plant Sci 65:335-343.

Rybicka EH (1996). Impact of mining and metallurgical industries on the environment in Poland. Appl Geochem 11:3-9.

Salomons W (1995). Environmental impact of metals derived from mining activities: processes, predictions, prevention. J Geochem Explor 52:5-23.

Shu WS, Ye ZH, Zhang CY, Wong MH (2005). Natural colonization of plants on five lead/Zinc mine tailings in Southern China. Restoration Ecology 13(1):49-60.

Shuman LM (1999). Organic waste amendments effect on zinc fractions of two soils. J Environ Qual 28:1442-1447.

Simón M, Ortiz I, García I, Fernández J, Dorronsoro C, Aguilar J (1999). Pollution of soils by the toxic spill of a pyrite mine (Aznalcóllar, Spain). Sci Total Environ 242:105-115.

Sutton P, Dick WA (1987). Reclamation of acidic mined lands in humid areas. Adv Agron 41:377-406.

Tordoff GM, Baker AJM, Willis AJ (2000). Current approaches to the revegetation and reclamataion of metalliferous wastes. Chemosphere 41:219-228.

Walker DJ, Clemente R, Roig A, Bernal MP (2003). The effects of soil amendments on heavy metal bioavailability in two contaminated soil Mediterranean soils. Environ Pollut 122:303-312.
Walker DJ, Clemente R, Bernal MP (2004). Contrasting effects of manure and compost on soil $\mathrm{pH}$, heavy metal availability and growth of Chenopodium album $\mathrm{L}$. in soil contaminated by pyritic mine waste. Chemosphere 57:215-224.

Williamson A, Johnson MS (1981). Reclamation of metalliferous mine wastes, pp. 185-212. In: Lepp NW (Ed.). Effect of Heavy metal pollution on Plants. Vol. 2. Metals in the Environment. Applied Science Publishers Ltd., Barking.

Williamson NA, Johnson MS, Bradshaw AD (1982). Mine waste rehabilitation: the establishment of vegetation on metal mine waste. Mining Journal Books, London.

Wong JWC, Ip CM, Wong MH (1998) Acid-forming capacity of lead-zinc mine tailings and its implications for mine rehabilitation. Environ Geochem Health 20:149-155.

Wong MH (2003). Ecological restoration of mine degraded soils, with emphasis on metal contaminated soils. Chemosphere 50:775-780.

Yazar Y (2010). Present situation of the Keçiborlu Sulphur Factory Flotation wastes and determination of its environmental effects. Akdeniz University, Science Institute, Department of Soil Science and Plant Nutrition. MSc Thesis, September 2010, $166 \mathrm{p}$.

Ye ZH, Wong JWC, Wong MH, Lan CY, Baker AJM (1999). Lime and pig manure as ameliorants for revegetation lead/zinc mine tailings: a greenhouse study. Bioresour Technol 69:3543. 